led to suppose by the writings of others. At the same time, of course, it may, and does, occur that an animal or human being is sensitised by a dose of foreign protein-e.g., serum-and dies suddenly on the administration subsequently of the smallest dose of the same protein after and within a certain time. It is, therefore, a matter of considerable importance that valuable lives should not be risked at the present time in the circumstances which now exist as regards serum production and therapy, when by simple measures all danger can be eliminated. Sera are given so often and with so little regard for the future-so far as the possibility of anaphylaxis is concerned-that it seems worth while to consider whether we should not take steps at once to mitigate the danger of which I have spoken.

Sera are, $I$ believe, at present practically all taken from immunised horses. Surely it would be a wiser course to immunise several different species of the larger animals with the various organisms against which horses are now commonly immunised. If this were done anaphylaxis, which is absolutely specific to the serum of any given species, could be certainly guarded against by using the sera of different animals, immunised against the same organisms, when more than one dose of serum was administered to the same individual after a short interval and within, say, 12 months, and each individual so treated should receive a card, or be marked in some way, for the instruction of those who treat him subsequently.

The matter is one of urgency and gravity; either there is no such thing as anaphylaxis or the course I have mentioned should immediately be adopted by those responsible for the preparation of the various sera.

Meanwhile, it may be worth while to remember that it is said that the fatal phenomena of anaphylaxis can be avoided if the serum be administered while the patient is under the influence of ether. I think we may disregard the statement that to produce anaphylaxis the two injections must be made in identical sites-subcutaneous, intrathecal, \&c.

I should also like to allude to another point concorning the administration of sera. Susceptible subjects may be made seriously ill with "serum sickness"; but this can be prevented, or subsequently mitigated, by the administration of large doses of calcium salts by the mouth; three doses, each consisting of two ounces of the liq. calcii lactat. B.P. Codex in half a pint of water, should be administered with four-hourly intervals on the day on which the serum is administered or the "sickness" develops. I can testify to the value of calcium lactate in these circumstances from a personal experience.-I am, Sir, yours faithfully,

Liverpool, Dec. 14th, 1914. W. BLAIR BELL.

\section{MEDICAL EDUCATION OF WOMEN IN LONDON.}

To the Editor of THE LANCET.

SIR,-The increase in the number of women entering upon the study of medicine in London makes it urgently necessary to increase the laboratory accommodation of the London (Royal Free Hospital) School of Medicine for Women. This is not a war appeal, but it appears to the council of the school to be justified even at a time like this by the need of the country for more doctors in the near future, and by the fact that this school is the only one in London at which women can obtain a medical education.

The school deserves help for its work in the past. Founded 40 years ago, when there were only two women on the British Medical Register, there are now about 1000, of whom over 600 are former students of the school.

The school deserves help for the work it is doing now. The annual entry has doubled in the last six years. 212 students are in attendance, and if the present annual entry be maintained this number will rapidly rise to 300 . It is a school of the University of London in the Faculty of Medicine. It has beautiful and suitable premises built 1899-1900, but they are not large enough for the present number of students. Additions to the laboratories, new research rooms, and more lecture rooms are essential. An adjoining site has been secured. Plans are prepared and approved, and building is to begin directly after Christmas.

The school deserves help for the work of the future. The demand for medical women constantly increases. In public departments throughout this kingdom, in sanatoria, in Poor-law institutions, in hospitals both in England and India, and as medical missionaries all over the world, they work in evergrowing numbers. At the present time medical women are urgently called upon to fill the places and supplement the work of the medical men serving with the army, and they are doing this both in this country and in France, so far as their numbers permit. This demand will be increased in the near future owing to the number of young men now joining the army, who might otherwise have studied medicine. Were twice as many to qualify as qualify now, all would be absorbed by these and other needs.

The council must raise $£ 25,000$ to pay for the additional buildings required and their equipment, and ask those interested in the work and medical education of women to provide this sum. Donations or promises should be sent to the London (Royal Free Hospital) School of Medicine for Women, 8 , Hunter-street, W.C., addressed to the honorary treasurer, Mr. M. J. Henderson, who joins with us in the appeal.

We are, Sir, yours faithfully,

E. GarRetT-ANDERSon, President.

F. D. ACland, Chairman.

Louisa B. Atidrich-Blake, Dean.

MAY THORNe, Hon. Secretary.

London (Royal Free Hospital) School of Medicine for Women, Dec. 14th, 1914.

\section{THE ETIOLOGY OF LEPROSY.}

To the Editor of THE LANCET.

SIR,--The letters in THE LANCET during August and September under the heading of "The Relation of Fish to Leprosy" induce me to raise briefly the question of the etiology of leprosy, which goes rather beyond the question of fish, be it fresh, salt, decomposed, or other.

It is really high time that the consideration of a subject of such engrossing importance should be restricted to the recording of facts and to analogical reasoning. What is being done throughout the world to sift the family history of the leper? Speaking for parts of the tropics where leprosy occurs, and of which I have personal experience, I can say that existing conditions are little likely to favour the acquisition of etiological facts. A lamentable process through the magistrate's court, sometimes a stay in a police cell, may be the committal 